\title{
The effect of surgical treatment on voice quality in Reinke's edema: an evaluation with vocal performance questionnaire and acoustic voice analysis
}

\author{
Reinke ödeminde cerrahi tedavinin ses kalitesi üzerine etkisi: \\ Ses performans anketi ve akustik ses analizi ile değerlendirme \\ Soner Taşar', Melek Kezban Gürbüz², Ercan Kaya², Erkan Özüdoğru², \\ Fatma Güney², Hamdi Çaklı , Armağan İncesulu ${ }^{2}$ \\ ${ }^{1}$ Department of Otorbinolaryngology, Eskişebir Government Hospital, Eskişebir, Turkey \\ ${ }^{2}$ Department of Otorbinolaryngology, Faculty of Medicine, Eskişehir Osmangazi University, Eskişehir, Turkey
}

\begin{abstract}
Objective: The aim of this study was to investigate the effect of surgical treatment of Reinke's edema on voice quality. The changes in voice quality caused by surgical treatment were evaluated by using voice performance questionnaire and acoustic voice analysis before and after surgery.

Methods: Vocal Performance Questionnaire and acoustic voice analyses with the help of Dr. Speech (Drs Tiger Inc., Seattle, WA, USA) software were performed preoperatively and at one month postoperatively in 21 patients with Reinke's edema who had received surgical therapy. Results: Reinke's edema was bilateral in all patients. According to the results of vocal performance questionnaires and acoustic voice analyses, the voice quality of patients improved significantly after surgery. At the end of the six month follow-up, the recurrence was detected only in one (4.7\%) patient.

Conclusion: In patients with Reinke's edema, the functional properties of vocal folds and the voice quality of patients can be successfully improved by surgical treatment.
\end{abstract}

Key words: Reinke's edema, surgical treatment, voice quality, questionnaire, voice analyses.

Reinke's edema is one of the benign mucosal diseases of the vocal cord, it develops as a result of the accumulation of gelatinous edematous fluid in superficial lamina propria of vocal folds (Reinke's space). This fluid accumulates in this region because of local impairment of lymphatic circulation or vascular congestion and stasis secondary to damage of the

\section{Özet}

Amaç: Bu çalışmada Reinke ödeminde cerrahi tedavinin ses kalitesi üzerine etkisi araştırılmışır. Cerrahi tedavinin ses kalitesinde meydana getirdiği değişiklikler, hastalara cerrahi öncesi ve sonrası ses performans anketi ve akustik ses analizi uygulanarak değerlendirilmiştir.

Yöntem: Reinke ödemi olan ve cerrahi tedavi uygulanan 21 hastaya ameliyat öncesi ve sonrası 1. ayda ses performans anketi ve Dr. Speech (Drs Tiger Inc., Seattle, WA, ABD) bilgisayarlı ses analiz programı kullanılarak akustik ses analizi yapıldı.

Bulgular: Hastaların tümünde Reinke ödemi bilateraldi. Ses performans anketi ve ses analizi sonuçlarına göre hastaların ses kalitesinde cerrahi tedavi sonrası istatistiksel olarak anlamlı derecede düzelme saptandı. Altı aylık takip sonunda sadece 1 hastada (\%4.7) nüks tespit edildi.

Sonuç: Reinke ödemli hastalarda vokal kordların fonksiyonel özellikleri ve hastanın ses kalitesi cerrahi tedavi ile başarılı bir şekilde iyileştirilebilmektedir.

Anahtar sözcükler: Reinke ödemi, cerrahi tedavi, ses kalitesi, anket, ses analizi

vessel walls. ${ }^{[1,2]}$ Reinke's edema are more frequently seen in women and often causes a coarse voice and hoarseness. Among its etiological factors, smoking, alcohol consumption, misuse of voice, chronic laryngitis, laryngopharyngeal reflux, allergy, inadequate fluid intake and systemic diseases like hypthyroidism can be enumerated. ${ }^{[2]}$
Correspondence: Melek Kezban Gürbüz, MD. Eskişehir Osmangazi Üniversitesi Tıp Fakültesi, Kulak Burun Boğaz Anabilim Dalı, Meşelik, Eskişehir, Turkey.

e-mail: mkezban@yahoo.com.tr

Received: March 12, 2013; Accepted: April 24, 2013; Published online: November 1, 2013
Online available at:

www.jmedupdates.org doi:10.2399/jmu.2013002003 QR code: 
In patients diagnosed at an early stage of the disease, vocal hygiene and voice therapy can provide sufficient improvement. However in patients where the size of the vocal cord mass increased extremely or in vocal cords with polypoid formations, surgery is the first-line therapy. As seen in all other vocal cord surgeries, during surgical treatment of Reinke's edema, medial surface of the vocal cord which is effective on phonation function of vocal cords, should be preserved. After surgical treatment improvements in voice qualities of the patients can be assessed by performance questionnaires and acoustic voice analysis. ${ }^{[-5]}$

In this study, in patients with Reinke's edema, voice performance questionnaire surveys and acoustic voice analysis were performed during pre- and postoperative periods in order to analyze the changes in voice quality caused by surgical treatment.

\section{Materials and Methods Study Group}

This study has a prospective design. Study group consisted of 21 patients presented to our clinic between December 2007 and December 2010 with complaints of voice disorders and initial diagnosis of Reinke's edema involving both cords. The patients had undergone surgical treatment because they didn't benefit from conservative and medical therapies as voice therapy, vocal hygiene and proton pump inhibitors. Patients with a past history of laryngeal surgery were not included in the study. Approval of the ethics committee of our university was obtained for our study and patients were informed about the study in writing.

\section{Preoperative Evaluation}

After routine otorhinolaryngeal examination of the patients, the condition of the larynx was evaluated priorly with the aid of fiberoptic endoscope, then videolaryngogastroboscope (VLS). Digital VLS recordings were archived using Scop View (Drs Tiger Inc., Seattle, WA, USA) computer software. Patients were warned against improper vocal hygiene and smoking and informed about potential risks and outcomes of the vocal cord surgery.

Voice performance questionnaire: All the patients were requested to complete 12- item Voice Performance Questionnaire (VPQ) forms recommended by Carding ${ }^{[6]}$ and translated fully into Turkish. In this questionnaire responses to each question were rated between 1 and 5 points so as to obtain total scores.

Acoustic voice analysis: Vocal Assessment part of the computed voice analysis software (Dr. Speech, Drs Tiger Inc., Seattle, WA, USA) was used to perform acoustic voice analy- sis. For voice analysis, the patients were requested to make an $/ \mathrm{a} /$ sound for the duration of 3 seconds in a modal voice $20 \mathrm{~cm}$ away from an EM-616 Condenser brand microphone and recordings were made at a sampling rate of 44,100 $\mathrm{Hz} / \mathrm{sec}$ and 16 byte amplitude.

\section{Surgical Technique}

Surgical treatment of all patients was realized under general anesthesia and with the aid of a microscope. Similar to the microflap technique recommended by Sataloff et al. for benign vocal cord lesions, an incision was made 1-2 cm away from anterior and posterior commissures and subepithelial region was dissected to aspirate fluid accumulated in the Reinke's space. ${ }^{[7]}$ Preserving vibratory part of the vocal cord, redundant mucosa was resected and flap was placed on the defect. In each patient, surgical procedure was applied in the same session for both vocal cords. However because of the risk of postoperative adhesion formation of between vocal cords, bilateral mucosa resection was not performed in the close vicinity of anterior commissure.

\section{Postoperative Follow-up and Evaluation}

On postoperative 5 th day, measures to be taken to achieve absolute voice rest and vocal hygiene were recommended. At postoperative first month, voice performance tests and acoustic voice analysis were reapplied in all patients. The patients were followed up for 6 months with respect to the presence of recurrences.

\section{Statistical Evaluation}

For the statistical analysis of parametric variables the Statistical Package for Social Sciences 15.0 for Windows (SPSS Inc., Chicago, IL, USA) was used. For variables with normal distribution paired $t$ test and for variables with nonnormal distribution Wilcoxon Signed Rank test were used. $\mathrm{p}<0.05$ was accepted as statistically significant.

\section{Results}

Our study population consisted of 12 (57.1\%) female and 9 male $(42.9 \%)$ patients. Median age of our patients was 48.04 (range 24 to 63) years. None of patients was professional voice user and all of them were past or current smokers. All the patients had bilateral Reinke's edema.

Table 1. Results of the voice performance questionnaire survey.

\begin{tabular}{lcc} 
& Mean \pm Standard deviation & p \\
\hline Preoperative & $49.10 \pm 1.70$ & $\mathrm{p}<0.001$ \\
Postoperative & $19.05 \pm 1.70$ & \\
\hline
\end{tabular}


Table 2a. Results of the acoustic voice analysis (I).

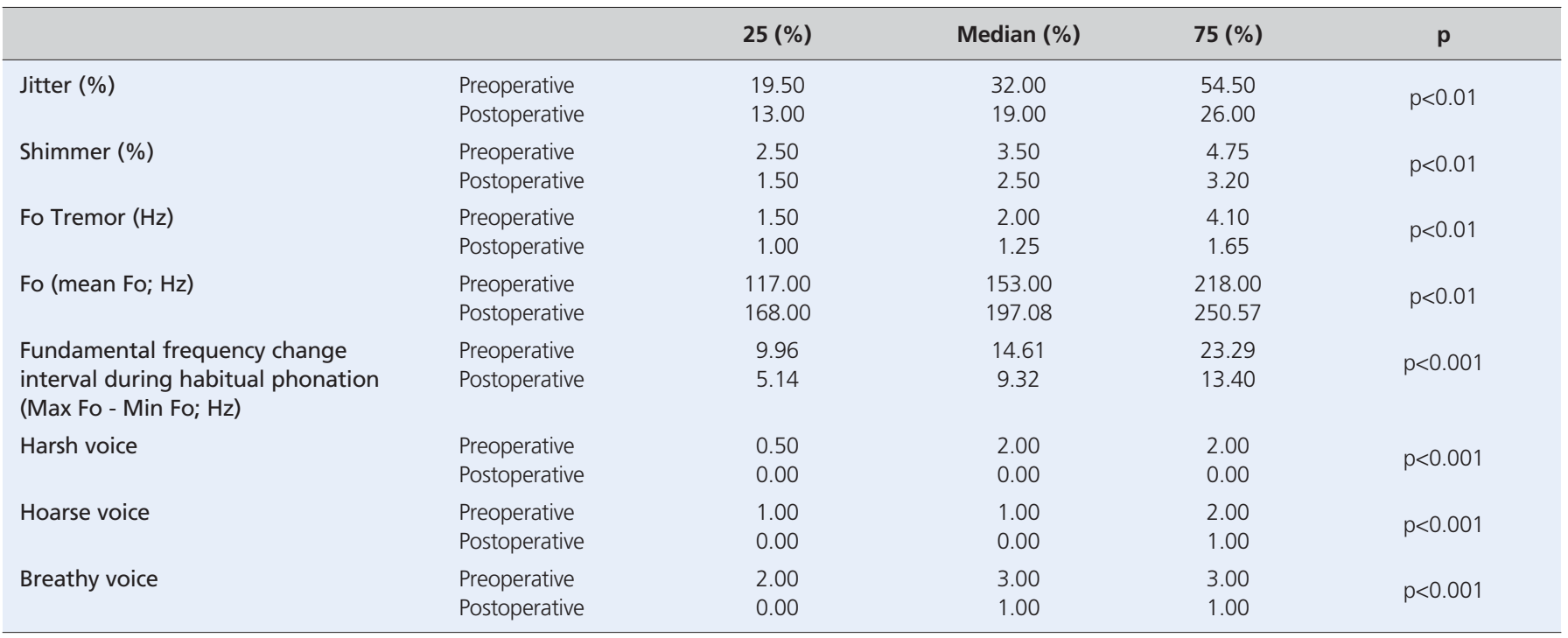

Results of the voice performance questionnaire surveys: Based on the responses given to the items of the questionnaire, during the postoperative period, a statistically significant decrease was detected in the voice complaints of the patients $(\mathrm{p}<0.001)$ (Table 1).

Results of the acoustic voice analysis: Statistically significant improvements were detected in all postoperative parameters $(\mathrm{p}<0.001)$ (Tables 2 and 3).

Postoperative follow-up: During the postoperative period, in none of the cases any web formation was detected on the anterior commissure. At postoperative 6th month of the follow-up period recurrence was observed in one $(4.7 \%)$ patient. It was learnt that this patient had started to smoke again, while all of our remaining patients quitted smoking.

\section{Discussion}

In the surgical treatment of Reinke's edema, drainage of edema or fibrous exudates and in case of need excision of the redundant and sagging mucosa of the vocal cord using endolaryngeal microsurgery under microscopic guidance are recommended. Excision using conventional surgical instruments can be mostly accomplished with microlaryngeal forceps, scissors and similar surgical instruments. However literature studies related to application of laser and microdebrider in the surgical management of Reinke's edema are also cited. ${ }^{[4,8]}$ Due to scarcity of these studies, information and outcomes about the success of microdebrider use in the surgical treatment of Reinke's edema are far from being adequate.

Irrespective of the surgical technique used in the treatment of Reinke's edema, every meticulous care should be exerted to preserve the integrity of medial aspect of the vocal cord which affects the quality of phonation. To that end, incision should be made on the upper surface of the vocal cord and extended laterally and mucosa should be elevated to aspirate edema or fibrous exudate with ease. In case

Table $\mathbf{2 b}$ b. Results of the acoustic voice analysis (II).

\begin{tabular}{llcc}
\hline & \multicolumn{2}{c}{ Mean \pm standard deviation } & p \\
\hline Habitual Fo & Preoperative & $9.74 \pm 4.38$ & $p<0.01$ \\
& Postoperative & $6.26 \pm 3.96$ & \\
Normalized noise energy $(\mathrm{dB})$ & Preoperative & $164.45 \pm 53.22$ & $\mathrm{p}<0.01$ \\
& Postoperative & $187.86 \pm 66.88$ & \\
HNR $(\mathrm{dB})$ & Preoperative & $17.90 \pm 4.33$ & $\mathrm{p}<0.001$ \\
& Postoperative & $23.79 \pm 3.86$ &
\end{tabular}


Table 3a. Statistical evaluations performed using parametres of Real Analysis Program (I).*

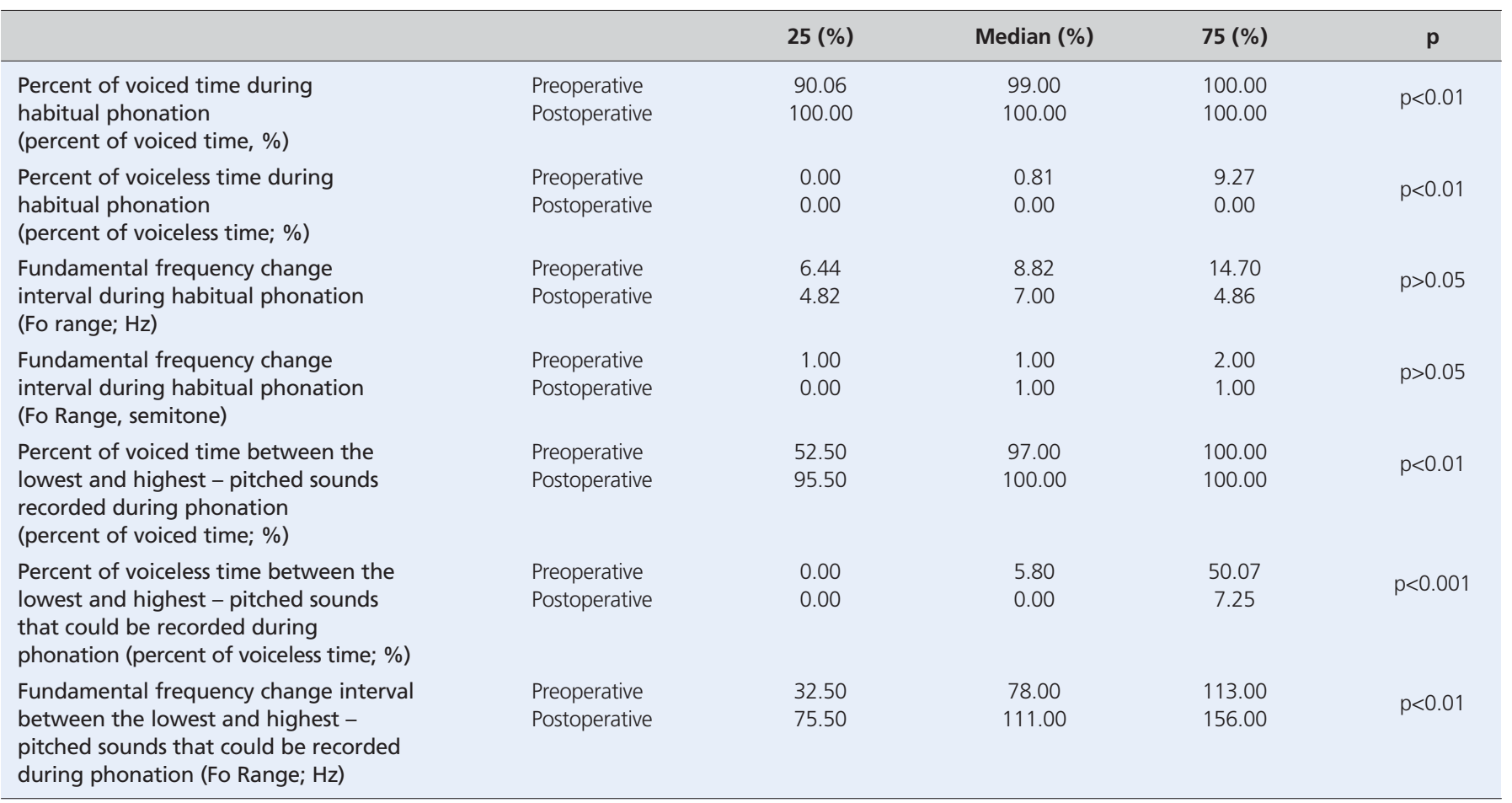

*For comparisons Wilcoxon Signed Rank test was used.

of need, redundant mucosa should be resected. In cases where mucosal layers should be preserved, epithelial incision only allows suction of the edematous fluid. During incision of the vocal cord mucosa, anterior commissure should be avoided. Otherwise, adhesions (web) might develop on the anterior commissure which intensely impairs voice quality during the postoperative period. Therefore, in cases where bilateral mucosal resection is required in the very close vicinity of anterior commissure, operation can be performed in two sessions because of potential postoperative web formation In our study, all operations were performed under general anesthesia with the aid of a microscope and using microflap technique described in detail in the "Materials and Methods" section of our article. Surgical procedure was performed for both vocal cords in a single session in all patients However because of the risk of web formation; bilateral mucosal incisions were not made in the vicinity of anterior commissure. As a result, adhesions on anterior commissure were not detected in any patient during the postoperative period.

Treatment success in benign mucosal diseases of the vocal cord as is the case in Reinke's edema, can be evaluated with voice performance questionnaire surveys and/or acoustic voice analysis. Voice performance questionnaire forms are used to measure the effects and severity of voice complaints on daily life activities. One of them is Voice

Table 3b. Statistical evaluations performed using parametres of Real Analysis Program (II).*

\begin{tabular}{llcc}
\hline & \multicolumn{1}{c}{ Mean \pm standard deviation } & p \\
\hline $\begin{array}{l}\text { Changes in fundamental } \\
\text { frequency between the highest }\end{array}$ & Preoperative & $7.10 \pm 4.88$ & $\mathrm{p}>0.05$ \\
and lowest voice pitches & Postoperative & $9.52 \pm 4.47$ & \\
(Fo Range; semitone) & & & \\
\hline
\end{tabular}

*For comparisons paired samples statistics was used. 
Handicap Index (VHI) which was formulated by the University of Pittsburgh Voice Center in 1997. Later on a modified version of this questionnaire (VHI-10) was advised and authors advocated easier application of this new version. ${ }^{[5,9]}$ Carding recommended another voice performance questionnaire in 1998 (Voice Performance Questionnaire [VPQ]) which consists of 12 items ${ }^{[6]}$ Deary et al. investigated use of VPQ and VHI in 330 patients and emphasized these scales can be applied in a short time with due ease and safety. ${ }^{[5]}$ In our study, Turkish version of VPI was applied without any problem. According to the results of our questionnaire, statistically significant improvements were detected in voice complaints of our patients during the postoperative period.

Acoustic voice analysis programs allow evaluation of acoustic parametres of the voice using computer-assisted software programs. Though these programs provide objective assessments, it can be affected by the type of voice recording, distance between the patient and the microphone, ambient noise and patient's compliance. ${ }^{[10]}$ In our study, since all recordings for voice analysis were made in a noiseless environment with the microphone held $20 \mathrm{~cm}$ away from the patients, any procedural problem was not encountered.

Though acoustic analyses reflect vocal cord dysfunctions, they are not useful in the differential diagnosis of pathologic conditions. Besides as cited above, they can be preferred in the evaluation of the improvements achieved with treatment of vocal cord diseases. ${ }^{[10]}$ Fundamental frequency ( $\mathrm{Fo}$ ) which is one of the voice parametres analyzed, indicates number of glottic cycles occurring and it is the most primitive voice frequency detected at the laryngeal level. Harmonic voice is an integer multiple of the fundamental frequency, the remaining types of voice are evaluated as 'noise.' Noise originates from incomplete closure of vocal cords or their disordered vibrations. Harmonics-tonoise ratio (HNR) correlates with dysphonia. In cases where vocal cord mass increases, as in Reinke's edema, values of fundamental frequency and HNR might decrease. ${ }^{[10,11]}$

Perturbation measurements which reflect variations in vocal cord vibrations (jitter and shimmer tests) evaluate acoustic characteristics of the voice and they are used frequently in voice analysis programs. ${ }^{[1]} \mathrm{Lim}$ et al. compared pre- and postoperative values for fundamental frequency, jitter, shimmer and HNR in 61 patients with Reinke's edema and detected increases in postoperative fundamental frequency and HNR values and decreases in jitter and shimmer parameters. ${ }^{[12]}$ They indicated that fundamental frequencies decrease with increasing severity of vocal cord edema. Accordingly they advocated that HNR parameter is more valuable in the evaluation of postoperative voice quality in patients with diffuse vocal cord edema. Honda et al. compared pre- and postoperative fundamental frequency, jitter and shimmer test results in 17 patients with Reinke's edema and detected a significant increase in postoperative values of fundamental frequency and meaningful decrease in jitter and shimmer test results. ${ }^{[8]}$ Results of our study are in accordance with these literature findings.

In audioperceptional evaluation of voice qualities of the patients with Reinke's edema, hoarseness, harshness and breathiness are predominant characteristics. In the Vocal Assessment program these characteristics can be analyzed in mathematical terms. Some literature studies detected significant improvements in hoarseness and breathiness parameters of the patients with Reinke's edema after microlaryngoscopic surgery. ${ }^{[3,13]}$ Results of our study are also comparable.

Smoking lead the way among etiological factors for Reinke's edema and quitting smoking during or before the treatment might favourably effect the treatment success. Also in our study, all of our patients except one person quitted smoking which might increase success rates of our surgical treatment.

\section{Conclusion}

In conclusion when postoperative alterations in all parameters analyzed were evaluated cumulatively, we think that if in cases with Reinke's edema, endolaryngeal microsurgery is performed meticulously by a surgeon with a comprehensive knowledge on vocal cord anatomy, functional capabilities of vocal cord and voice quality can be recovered successfully. However patient's pre- and postoperative compliance to vocal hygiene measures will affect the success and outcomes of surgery

Conflict of Interest: No conflicts declared.

\section{References}

1. Marcotullio D. Magluilo G. Pezona T. Reinke's edema and risk factors: clinical and histopathologis aspects. Am J Otolaryngol 2002;23: 81-4.

2. Tillmann B, Rudert H, Schünke M, Werner JA. Morphological studies on the pathogenesis of Reinke's edema. Eur Arch Otorhinolaryngol 1995;252:469-74.

3. Zeitels SM, Hillman RE, Bunting GW, Vaughn T. Reinke's edema: phonatory mechanisms and management strategies. Ann Otol Rhinol Laryngol 1997;106:533-43.

4. Murray T, Abitbol J, Hersan R. Quantitative assessment of voice quality following laser surgery for Reinke's edema. J Voice 1999; $13: 257-64$ 
5. Deary IJ, Webb A, Mackenzie K,Wilson JA, Carding PN . Short self report voice semptom scales: Psychometric characteristics of the voice handicap index-10 and the vocal performance questionnaire. Otolaryngol Head Neck Surg 2004;131:232-5.

6. Carding PN, Horsley IA, Docherty GJ. The efectiveness of voice therapy for patients with non-organic dysphonia. Clin Otolaryngol 1998;23:310-18.

7. Sataloff RT, Spiegel JR, Heuer RJ, et al. Laryngeal mini-microflap: a new technique and reassessment of the microflap saga. J Voice 1995;9:198-204.

8. Honda K, Haji T, Maruyama H. Functional results of Reinke's edeme surgery using a microdebrider. Ann Otol Rhinol Laryngol 2010;119:32-6.
9. Rosen CA, Lee AS, Osborne J, Zullo T, Murry T. Development and validation of the voice handicap index-10. Laryngoscope 2004; 114:1549-56.

10. Sataloff RT. Professional voice. The science and art of clinical care. New York: Raven Press; 1991.

11. Kılıç MA, Okur E. CSL ve Dr. Speech ile ölçülen temel frekans ve perturbasyon değerlerinin karşılaştırılması. KBB Ihtis Derg 2001; 8:152-7.

12. Lim JY, Choi JN, Kim KM, Choi HS. Voice analysis of patients with diverse types of Reinke's edema and clinical use of electroglottographic measurements. Acta Otolaryngol 2006;126:62-9.

13. Sommer C, Schults-Coulon HJ. Long-term results after microlaryngoscopic removal of Reinke's edema. HNO 2007;5:365-74.

This is an open access article distributed under the terms of the Creative Commons Attribution-NonCommercial-NoDerivs 3.0 Unported (CC BYNC-ND3.0) Licence (http://creativecommons.org/licenses/by-nc-nd/3.0/) which permits unrestricted noncommercial use, distribution, and reproduction in any medium, provided the original work is properly cited.

Please cite this article as: Taşar S, Gürbüz MK, Kaya E, Özüdoğru E, Güney F, Çaklı H, İncesulu A. The effect of surgical treatment on voice quality in Reinke's edema: an evaluation with vocal performance questionnaire and acoustic voice analysis. J Med Updates 2013;3(2):56-61. 